\title{
A Study to Check the Applicability of Fama and French, Three-Factor Model on KSE 100-Index from 2004-2014
}

\author{
Nahzat Abbas ${ }^{1}$, Jahanzeb Khan ${ }^{1}$, Rabia Aziz ${ }^{1} \&$ Zain Sumrani $^{1}$ \\ ${ }^{1}$ Department of Management Sciences, Shaheed Zulfikar Ali Bhutto Institute of Science and Technology, Pakistan \\ Correspondence: Nahzat Abbas, Department of Management Sciences, Shaheed Zulfikar Ali Bhutto Institute of \\ Science and Technology, Pakistan. E-mail: nahzat.abbas@yahoo.com
}

Received: November 21, 2014

Accepted: December 11, $2014 \quad$ Online Published: December 29, 2014

doi:10.5430/ijfr.v6n1p90

URL: http://dx.doi.org/10.5430/ijfr.v6n1p90

\begin{abstract}
This study aims to test the explanatory power of Fama and French three factor model (1993) in explaining cross-sectional average return for Pakistan's equity market for the time frame of 10 years from 2004-2014. The sample includes firms that traded on KSE-100 index from 2004-2014. Six portfolios were formed by the intersection of two size portfolios and three value portfolios. Excess monthly returns of the six portfolios i.e. the dependent variable were individually regressed against market premium, size premium and value premium (MRP, SMB and HML) i.e. the independent variables to test the validity of Fama and French three factor model.

Along the line of original Fama \& French, this study aims to provide valuable insights into components of excess returns and lay ground work towards further studies in this domain. An important insight it is bound to show is whether BE/ME \& size factors hold as proxies for time-varying systematic risk as is proclaimed by past researches.
\end{abstract}

Keywords: value investing, value premium, size premium, portfolio management, investment strategies, asset pricing model

\section{Introduction}

\subsection{Introduction}

The Capital Asset Pricing Model (CAPM), developed by Sharpe (1964) and Lintner (1965), has been long used by academics and practitioners to explain the relationship between risk and expected returns of an asset. This model takes into account only one risk factor which is the excess market portfolio return (Market premium). The CAPM model explains that covariance of portfolio return with the market portfolio return has an important role in explaining variations on the excess portfolio return. An empirical study by Fama and French in 1992 shows that covariance of portfolio return and market return does not explain the excess portfolio return changes and have little or no power in explaining cross-sectional variations in returns on equity.

Research conducted Banz (1981), Basu (1938), Rosenberg, Reid and Lanstein (1985) and Lakonishok, Shleifer and Vishny (1994), show that a firm's average stock return is related to firm's size (market capitalization), book to market equity (Book value of common equity/Market value), Earning to Price (E/P), cash flow to price (C/P) and past sales growth. (FF, 1996)

Fama and French (1996) argue that these anomalies (patterns in average stock returns that are not explained by the CAPM) are related and are captured by the three factor model of Fama and French (1993). Fama and French, three factor model states that the expected excess returns on a portfolio $\left[E\left(R_{i}-R_{f}\right)\right]$ is explained by the sensitivity of its return to three factors:

i. Excess return on market portfolio i.e. market premium $\left(R_{i}-R_{f}\right)$

ii. The difference between the return on small stock portfolio and big stock portfolios i.e. size premium (SMB)

iii. The difference between returns of high book to market stock portfolios and low book to market stocks portfolio i.e. value premium (HML)

According to Fama and French (1992), excess expected return on a portfolio i is, 
Where,

$$
\left(R_{i}-R_{f}\right)=b_{i}\left[\left(R_{m}-R_{f}\right)+s_{i}(S M B)+h_{i}(H M L)\right.
$$

$E\left(R_{m}-R_{f}\right), E(S M B)$ and $E(H M L)$ represent the expected premiums and $b_{i}, s_{i}$ and $h_{i}$ represents the slopes in the time series regression,

$$
\left(R_{i}-R_{f}\right)=\alpha_{i}+b_{i}\left(R_{m}-R_{f}\right)+s_{i}(S M B)+h_{i}(H M L)+\varepsilon_{i}
$$

According to Fama and French (1995), book to market equity and slopes on HML represents relative distress. Firms which are weak and have low earnings tend to have high book to market ratio and positive slopes on HML, whereas firms which have persistent high earnings have low BE/ME and negative slopes on HML. Chan and Chen (1991) provided evidence in there research that there is covariation in returns related to relative distress that is not captured by the market return and is compensated in average returns. Hence, use of HML to explain returns are justified in Chan and Chen (1991) research. Similarly Huberman and Kandel (1987) provided evidence in there paper that there is covariation in the returns on small stocks that is not captured by the market return and is compensated in average returns and therefore use of SMB to explain returns is in line with the evidence. (FF, 1996)

Fama and French, three factor model, absorbs most of the anomalies of the CAPM. The combination of size and book to market equity absorbs the opposite roles of market leverage and book leverage in average returns and the relationship between $\mathrm{E} / \mathrm{P}$ and average return. (FF, 1992)

FF model adds two additional risk factors to the CAPM in order to better explain the return variations and increase the explanatory power of CAPM.

The aim of this study is to test applicability of Fama and French three factor model using Pakistani equity market data. The study also aims to identify whether the risk factors identified by FF (1992) are good indicators for constructing portfolios. It is important for investor to identify the factors which affect portfolio returns.

\subsection{Literature Review}

Since Efficient Market Hypothesis (Markowitz, 1959), investors and academicians have been captivated and involved in the discussion towards optimum portfolio, risk minimization and characteristics of asset return. It specified a continuum of efficient portfolios along efficient portfolio frontier (Markowtiz, 1959). This led to an era of exhaustive research along the lines of risk and return.

Capital Asset Pricing Model by Sharpe (1964) and Lintner (1965) improved this model by introducing risk free asset in this model and combined with the assumption of unlimited buying and selling at a constant rate ' $r$ ', CAPM provided a unique point for an efficient portfolio and pave way for the derivation of numerous efficient portfolios as a combination of this single portfolio and Risk Free Asset. Along this line, CAPM states that asset returns are a function of Market Beta (covariance between asset and market portfolio). Though it is mathematically sound and simple in its implication, it didn't fully explain asset return when tested against past returns. To improve predictive power of CAPM different researchers over time have tried to improve on this model by finding other explanations towards this anomaly either by tweaking methodology, adding further assumptions, adding variables or combination of these. All these have led to some remarkable insights into predictive power of Beta and its limitations.

Amongst these were different researches over the past which have attempted to show different variables as standing proxies for different risks as rewards for asset returns. Merton in his paper (Note 1) found that expected returns on risky assets might differ from the risk free rate even when they have no systematic risk (Merton, 1973). Reinganum's study suggests that the simple one period CAPM is misspecified by documenting empirical anomalies. Their study provides an evidence for the size factor in explaining cross-sectional average return of an asset. They also found that Size effect largely incorporate the E/P effect (Reinganum, 1981). Banz also provided evidence that the CAPM is misspecified and there are other factors which explain the cross-sectional average return of an asset. Banz found strong size effect in cross-sectional average returns of US stocks for at least forty years. According to his study the size effect exists but the reason for its existence wasn't found (Banz, 1981). Gibbons also found that when market beta are taken alone for explaining cross-sectional average returns on US stocks from 1926-1975, the practical content of the CAPM is rejected for the period with a significance level of less than 1\% (Gibbons, 1982).

Research conducted by Banz (1981), Basu (1938), Rosenberg, Reid and Lanstein (1985) and Lakonishok, Shleifer and Vishny (1994), found that a firm's average stock return is related to other firm specific factors as well. These studies found that a firm's average stock return is related to firm's size (market capitalization), book to market equity (Book value of common equity/Market value), Earning to Price (E/P), cash flow to price (C/P) and past sales growth (FF, 1996). 
H. Bower, et al. provided evidence that market risk is not the only factor which explains the cross-sectional average return (H. Bower, et, al, 1984). Josef and Andrew found that value stocks are fundamentally more risky. They were of the opinion investors in value stocks, such as high book- to market stocks, bear higher fundamental risk of distress firm, and their higher average returns are simply compensation for this risk that value premium is a compensation for risk in a multifactor version of Merton's (1973) intertemporal capital asset pricing model (ICAPM) or Ross's (1976) arbitrage pricing theory (APT). Consistent with this view, Fama and French (1993) document covariation in returns related to BE/ME beyond the covariation explained by the market return, also, Fama and French (1995) show that there is a $\mathrm{BE} / \mathrm{ME}$ factor in fundamentals (earnings and sales) like the common factor in returns. Fernandez says that the Fama-French factors SMB and HML jointly provide statistically significant explanatory power across almost all the sample return horizons. He argues that SMB and HML proxy for measures of market risk not captured by the CAPM and that the FF factors are more superior in actual use (Fernandez, 2002). Along the same line, Kothari, et, al, found that average returns do reflect compensation for beta risk (if betas are measured at annual interval), however, beta alone does not account for all the cross-sectional variation in expected returns as explained by the CAPM (Kothari, 1995).

The shortcomings of the CAPM model led to the formation of multifactorial models. According to Martin \& Sydney in response to the failure of CAPM, Fama and French (1993) develop a three-factor model, with factors related to firm size, book-to-market equity, and the aggregate stock market (Martin and Sydney, 2001).

Fama and French came up with three factor model, in order to improve the explanatory power of CAPM. An empirical study by Fama and French (1992) shows that covariance of portfolio return and market return does not explain the excess portfolio return changes and have little or no power in explaining cross-sectional variations in returns on equity. Fama and French found that that relation between market $\beta$ and average return on stocks listed on NYSE disappear during 1963-1990 period. Their tests do not support the prediction of SLB model, that average stock returns are positively related to market $\beta$. Results of the study found that two easily measured variables, size and book to market equity, explain the cross-section of average returns. FF (1992) found strong relation between BE/ME and average stock return on NYSE stocks from 1963-1990.

Fama and French Three Factor Model (1993) incorporates market premium, value premium and size premium as predictive variables towards excess return of a portfolio. The model proposes portfolio formation on the basis of market capitalization, book-to-market and earning-to-price since they give better perspective into excess portfolio return ((Fama and French, 1992) (Lakonishok, Shleifer, and Vishny, 1994) (Chan, et, al, 1991)). Adam, et, al, found that the two factors, SMB and HML added by Fama and French (1993), prove to be a better measure for scrutinizing a portfolio's performance. They highlight that annual excess return is contributed largely by value and size exposure than by the skills of the portfolio managers (Borchert, et al. 2003). Also, the Book-to-market ratio (value factor) largely captured the variation in the returns of the assets in a study based on equity markets of 7 countries (Carlo, et al. 1993). Lu Zhang, (2005) explored the impact of value premium; (return of high BE/ME minus the return of low BE/ME companies), and found that the value factor works as a proxy for state of variability in times of financial uncertainty.

A standing pillar for both CAPM and Fama and French model lies on Market Efficiency (Fama, 1998). Market Efficiency states that investors make informed decisions. Fama in his paper states that market efficiency holds and that under-reaction (Note 2) to information is about as common as over-reaction (Note 3) to information (Fama, 1998). With this premise, FF3 model states that the expected excess returns on a portfolio is explained by the sensitivity of its return to three factors: (1) Excess return on market portfolio i.e. market premium (2) The difference between the return on small stock portfolio and big stock portfolios i.e. size premium (SMB) and (3) The difference between returns of high book to market stock portfolios and low book to market stocks portfolio i.e. value premium (HML). Their study found that market beta fails to explain the average returns on NYSE, AMEX and NASDAQ stocks for 1963-1990, while size and book-to-market equity captured the cross-sectional variation in average returns that is related to leverage and E/P (Fama and French, 1992). Andrew and Joseph second Fama and Fench in that the book-to-market effect appears to be a strong CAPM anomaly that many researchers consider to be a significant risk factor (Andrew and Joseph, 2005). Moreover, Fama and French (1995) study provides evidence that size and BE/ME factors are related to profitability.

Along with previous research, Fama \& French also suggest existence of value premium in stock returns (FF 2006). Their selection of Value and Size factors are further strengthened by research findings complementing these factors as being proxies for time-varying systematic risk. Both factors have also been found to proxy firm characteristics (Note 4) such as $\mathrm{C} / \mathrm{P}, \mathrm{E} / \mathrm{P}$, leverage, firm investment and others in asset returns.

Research done by Jaehoon, et al. incorporates changes in term spread and default spread as proxies to SMB and HML factors of FF3. They are of the opinion that given that default spread and term spread act as good macroeconomic variables, connected to fluctuation in business cycle and well known to forecast aggregate stock returns (Stambaugh, 
1986), Fama and French (1989)), these ought to be used in lieu of Value and size factor. Their research suggests that changes in term and default spread contain most of the implications of SMB and HML. (Lee, 2001). Given previous research linking value and size factor to systematic risk, conclusion can be drawn that size and value factors incorporates default risk and term risk.

Kenneth Lam while testing CAPM and Three Factor Model also seems to favor FF3 model but concludes that Fama and French Three Factor Model may be portfolio, test and period specific (Kenneth Lam, 2005).

FF3 model has been applied to various equity markets with numerous conclusive results showing reasonable predictive power of FF3 factors in asset returns. (Note 5)

Given substantial evidence linking three factors of FF3 with asset return, in this particular research, we will attempt to apply FF3 model on KSE 100 index to try and see if FF3 factors provide sufficient explanatory power towards asset return with sufficient significance.

\subsection{Research Objectives}

The objective of this study is to test the applicability of Fama and French Three-Factor model on Karachi Stock Exchange 100 Index and to,

i. Observe the impact of market premium on excess portfolio returns

ii. Observe the impact of size premium (SMB) on excess portfolio return

iii. Observe the impact of value premium (HML) on excess portfolio return

\subsection{Hypothesis}

Multivariate regression model will be applied to test the validity of the model, expressed below:

$$
\left(R_{i}-R_{f}\right)=\alpha_{i}+b_{i}\left(R_{m}-R_{f}\right)+s_{i}(S M B)+h_{i}(H M L)+\varepsilon_{i}
$$

The following hypothesis will be tested,

$$
\begin{aligned}
& H_{1}: \alpha_{i} \neq 0 \\
& H_{2}: b_{i} \neq 0 \\
& H_{3}: s_{i} \neq 0 \\
& H_{4}: h_{i} \neq 0
\end{aligned}
$$

Fama and French three factor model will hold true for KSE 100-index if intercept $\left(\alpha_{i}\right)$ is not significant i.e. statistically 0 and the three slope coefficients $\left(b_{i}, s_{i}, h_{i}\right)$ are significant i.e. statistically different from 0 .

\section{Research Method}

\subsection{Sample Size}

We have taken KSE-100 index firms (as recomposed on $19^{\text {th }}$, September, 2014) as sample for our study. To be included in the sample firms must have at least 24 months data available. Firms that have negative Book equity are excluded from the study. We have selected a time period of 10 years from 2004-2014 for this study.

\subsection{Sample Method}

\section{Dependent \& Independent Variable}

Excess Market Portfolio Return is the Dependent Variable whereas Market Risk Premium, Size Premium \& Value Premium are the Independent Variables shown earlier in equation (i).

Excess Portfolio Return is the difference between Portfolio Return and Risk Free Rate. 3 month T-bill rate is used as proxy for the risk free rate.

Market Premium is the difference between Market Return and Risk Free Rate. Whereas, Size Premium is the difference between returns offered by Small Stocks \& return offered by Big Stocks (SMB). Lastly, Value Premium is difference between return offered by High Book to Market or value stocks (Book to Market Value hereafter referred to as $\mathrm{B} / \mathrm{M})$ \& return offered by Low B/M Stocks or growth stocks (HML).

\section{Portfolio Formation}

\section{Elements}

All the stocks listed on KSE 100-index will be divided on the basis of their market capitalization (ME) into small (S) and big (B) portfolios. Stocks with market capitalization above the median market capitalization are categorized as big stock and stock with market capitalization below the median as categorized as small stocks (S). 
Stocks are also grouped into three portfolios High, Medium and Low $(\mathrm{H}, \mathrm{M}, \mathrm{L})$ on the basis of their Book to Market equity, based on the breakpoint, top $30 \%$, middle $40 \%$ and bottom $30 \%$. Six portfolios are obtained by the intersection of two size $(\mathrm{S}, \mathrm{B})$ and three value portfolios $(H, M, L)$. These six portfolios are $S / H, S / M, S / L, B / H, B / M$, $\mathrm{B} / \mathrm{L}$

Portfolios are formed yearly. The BE/ME ratio used to form portfolios in June of year $t$ is then book common equity for the fiscal year ending in calendar year $\mathrm{t}-1$, divided by market equity at the end of December of $\mathrm{t}-1$.

\section{Portfolio return}

Individual Portfolio Return is calculated as the sum of value weighted return of each individual stock within its categorization over time' $t$ '.

Individual Stock Return is calculated as

$$
R_{i t}=\operatorname{Ln}\left[P_{t} / P_{t-1}\right]
$$

Where $P_{t}$ and $P_{t-1}$ are the closing price on day $\mathrm{t}$ and $\mathrm{t}-1$. Since KSE-100 index is a total return index, therefore we use the above formula to calculate individual stock return.

Return on Market Portfolio is calculated using historical data to find return difference over time ' $t$ ' ( $\left(t-t_{1}\right)$. Value-weight monthly returns on the portfolios are calculated from July to the following June.

Excess Portfolio return is the difference between value weighted portfolio return and the risk free rate.

SMB is calculated as;

$\mathrm{SMB}=$ Average return of $(\mathrm{SL}, \mathrm{SM}, \mathrm{SH})$ portfolio minus average return of $(\mathrm{BL}, \mathrm{BM}, \mathrm{BH})$ portfolio

$$
S M B=[(S L+S M+S H)-(B L+B M+B H)] / 3
$$

Similarly, HML is calculated as;

$\mathrm{HML}=$ Average return of $(\mathrm{SH}, \mathrm{BH})$ portfolio minus average return of (SL, BL) portfolio.

$$
H M L=[(S H+B H)-(S L+B L)] / 2
$$

\subsection{Research Type}

The study is a quantitative study based on longitudinal cross sectional analysis.

\subsection{Primary and Secondary Sources of Data}

Our study is based on secondary research. All the data has been take from Karachi Stock Exchange website. (www.kse.com.pk)

Risk free rates are taken from www.fma.com.pk.

\section{Theoretical Framework}

\subsection{Framework}

According to Fama and French (1992), excess expected return on a portfolio $\mathrm{i}$ is,

$$
\left(R_{i}-R_{f}\right)=b_{i}\left[\left(R_{m}-R_{f}\right)+s_{i}(S M B)+h_{i}(H M L)\right.
$$

Where,

$\left(R_{m}-R_{f}\right),(S M B)$ and $(H M L)$ represent the expected premiums and $b_{i}, s_{i}$ and $h_{i}$ represents the slopes in the time series regression,

$$
\left(R_{i}-R_{f}\right)=\alpha_{i}+b_{i}\left(R_{m}-R_{f}\right)+s_{i}(S M B)+h_{i}(H M L)+\varepsilon_{i}
$$

\subsection{Explanation of Framework}

$\left(R_{i}-R_{f}\right)$ represents the excess portfolio return which is the dependent variable, $\left(R_{m}-R_{f}\right)$, (SMB) and (HML) represent the market premium, size premium and value premium respectively and are the independent variables.

$b_{i}, s_{i}$ and $h_{i}$, represent the slopes of $\left(R_{m}-R_{f}\right),(\mathrm{SMB})$ and (HML) respectively.

The dependent variable i.e. excess portfolio return $\left(R_{i}-R_{f}\right)$ is regressed against the independent variables i.e. market premium $\left(R_{m}-R_{f}\right)$, size premium (SMB) and value premium (HML).

\subsection{List of Definitions \& Variables}

- Excess portfolio return= Value weighted portfolio return - risk free rate 
- $\quad$ Market premium= Market return - risk free rate

- Size premium $=$ Average return of $(\mathrm{S} / \mathrm{L}, \mathrm{S} / \mathrm{M}, \mathrm{S} / \mathrm{H})$ portfolio minus average return of $(\mathrm{B} / \mathrm{L}, \mathrm{B} / \mathrm{M}, \mathrm{B} / \mathrm{H})$ portfolio

- Value premium= Average return of $(\mathrm{S} / \mathrm{H}, \mathrm{B} / \mathrm{H})$ portfolio minus average return of $(\mathrm{S} / \mathrm{L}, \mathrm{B} / \mathrm{L})$ portfolio

\section{Results}

Regression is run on the gathered data of KSE-100 index to obtain estimation results.

Table 1. Mean, standard deviation and correlation of the monthly explanatory returns (annualized) in the three factor time series regression (July, 2004 to June 2014, 120 monthly observations)

\begin{tabular}{llllll}
\hline & Mean & St. Deviation & \multicolumn{3}{c}{ Correlation } \\
\hline & & & $\boldsymbol{R} \boldsymbol{m}-\boldsymbol{R} \boldsymbol{f}$ & $\boldsymbol{S M B}$ & $\boldsymbol{H M L}$ \\
\hline$R m-R f$ & 0.03 & 0.07 & 1.00 & & \\
$S M B$ & 0.22 & 0.72 & -0.24 & 1.00 & \\
$H M L$ & 0.24 & 0.81 & 0.18 & -0.03 & 1.00 \\
\hline
\end{tabular}

From the correlation data in Table 1, we determine weak correlation between independent variable hence there is absence of multicollinearity.

Regression equation (ii) is used to estimate the effect of independent variables on dependent variables. Table 2 summarizes the results of estimation.

Table 2. Regression results summary

\begin{tabular}{|c|c|c|c|c|c|c|}
\hline & \multicolumn{6}{|c|}{ Book-to-Market Equity } \\
\hline & \multicolumn{3}{|l|}{ Intercept } & \multicolumn{3}{|l|}{$\mathrm{p}$-value } \\
\hline Size & Low & Medium & High & Low & Medium & High \\
\hline Small & -0.004 & -0.005 & 0.008 & 0.395 & 0.263 & 0.046 \\
\hline \multirow[t]{3}{*}{ Big } & 0.004 & -0.005 & -0.004 & 0.058 & 0.137 & 0.001 \\
\hline & \multicolumn{6}{|c|}{ Book-to-Market Equity } \\
\hline & \multicolumn{3}{|l|}{ Slope $\left(b_{i}\right)$} & \multicolumn{3}{|l|}{ p-value } \\
\hline Size & Low & Medium & High & Low & Medium & High \\
\hline Small & 1.015 & 0.833 & 1.125 & 0.000 & 0.000 & 0.000 \\
\hline \multirow[t]{3}{*}{ Big } & 1.015 & 1.045 & 0.949 & 0.000 & 0.000 & 0.000 \\
\hline & \multicolumn{6}{|c|}{ Book-to-Market Equity } \\
\hline & \multicolumn{3}{|l|}{ Slope $\left(s_{i}\right)$} & \multicolumn{3}{|l|}{$\mathrm{p}$-value } \\
\hline Size & Low & Medium & High & Low & Medium & High \\
\hline Small & 0.965 & 0.701 & 0.863 & 0.000 & 0.000 & 0.001 \\
\hline \multirow[t]{3}{*}{ Big } & -0.123 & -0.123 & -0.084 & 0.000 & 0.016 & 0.000 \\
\hline & \multicolumn{6}{|c|}{ Book-to-Market Equity } \\
\hline & \multicolumn{3}{|l|}{ Slope $\left(h_{i}\right)$} & \multicolumn{3}{|l|}{ p-value } \\
\hline Size & Low & Medium & High & Low & Medium & High \\
\hline Small & -0.531 & 0.123 & 0.761 & 0.000 & 0.071 & 0.000 \\
\hline Big & -0.139 & 0.103 & 0.485 & 0.000 & 0.022 & 0.000 \\
\hline
\end{tabular}

In Table 2, the regression is estimated using monthly returns. 
Table 3 summarizes the adjusted R-Square results of each of the six portfolios' obtained through regression estimation. Table 3. Adjusted R-Square values for six portfolios

\begin{tabular}{llll}
\hline \multicolumn{4}{l}{ Book-to-Market Equity } \\
\hline Size & Low & Medium & High \\
\hline Small & 0.79 & 0.62 & 0.87 \\
Big & 0.92 & 0.84 & 0.80 \\
\hline
\end{tabular}

Table 4 summarizes the F-statistics values and F significance of each of the six portfolios

Table 4. F Values for six portfolios

\begin{tabular}{lllllll}
\hline \multicolumn{3}{l}{ Book-to-Market Equity } & & & \\
\hline & F-values & & & F significance & \\
\hline Size & Low & Medium & High & Low & Medium & High \\
\hline Small & 147.70 & 65.60 & 262.63 & 0.00 & 0.00 & 0.00 \\
Big & 463.82 & 207.16 & 155.48 & 0.00 & 0.00 & 0.00 \\
\hline
\end{tabular}

For the model to hold true, we stated earlier that the intercept in the equation (ii) should be insignificant i.e. close to zero and the coefficient $b_{i}, s_{i}$ and $h_{i}$ should be significant i.e. away from zero. From the regression results summarized in Table 1, we find that the intercepts of all six portfolios are insignificant, however $\mathrm{p}$ values for five portfolios out of six is found to be unfavourable i.e. more than 0.05 . Value of coefficient $b_{i}$ and $s_{i}$ is found to be significant for all 6 portfolios with highly favorable p-values. However, value of coefficient $h_{i}$ is found to be significant for five portfolios ( $\mathrm{S} / \mathrm{L}, \mathrm{S} / \mathrm{H}, \mathrm{B} / \mathrm{L}, \mathrm{B} / \mathrm{M}, \mathrm{B} / \mathrm{H})$ but insignificant for one portfolios $(\mathrm{S} / \mathrm{M})$. The two portfolios $\mathrm{S} / \mathrm{M}$ and $\mathrm{B} / \mathrm{M}$ are the portfolios which have not been used in construction of value and growth portfolios and hence we find slope of HML for one of these portfolios to have unfavourable results. F significance shows favourable estimation results for all six portfolios meaning that the three independent variables (Market Premium, Size Premium and Value Premium) do a good job at explaining excess portfolio returns. Fama and French in their studies formed diversified portfolios of NYSE, Amex and NASD stocks and through regression estimation found that intercepts are close to zero. On the basis of the findings they concluded that the Fama and French three factor model does a good job in explaining stock returns. (Fama and French, 1993)

Fama and French found that the slope of SMB factor which captures the size effect in stock returns was found to be higher for small stocks than for big stocks. The difference in the SMB slopes for small and big stocks, along with positive average SMB return, explains the higher returns on small stocks. They also found that high BE/ME stocks are more sensitive to HML than the low BE/ME stocks. (Fama and French, 1993) Our findings are in line with the findings of Fama and French. In Table 2, the slope of SMB factors for small stock portfolios $(\mathrm{S} / \mathrm{L}, \mathrm{S} / \mathrm{M}, \mathrm{S} / \mathrm{H})$ are found to be positive and higher than the slope of big stock portfolios $(\mathrm{B} / \mathrm{L}, \mathrm{B} / \mathrm{M}, \mathrm{BH})$ which are found to be negative and the average SMB return or mean of SMB is found to be positive (see Table 1), hence we can determine that small stocks listed on KSE-100 index from July 2004 to June 2014 had higher returns than large stocks. Our research findings also support that value stocks (High BE/ME stocks) have higher return than growth stock (Low BE/ME stocks). The slope of high $\mathrm{BE} / \mathrm{ME}$ portfolios $(\mathrm{S} / \mathrm{H}, \mathrm{B} / \mathrm{H})$ is found to be positive and higher than the slope of low BE/ME portfolios ( $\mathrm{S} / \mathrm{L}$, $\mathrm{B} / \mathrm{L}$ ) and the average HML return or mean of HML is found to be positive (see Table 1), hence we determine that high $\mathrm{BE} / \mathrm{ME}$ stocks have higher return than low BE/ME stocks.

The slope of market risk factor with favourable p-values is also found to be significant. Fama and French (1993) found that beta values were mostly around 1. Similar to Fama and French (1993) research findings, we also find that the beta values are mostly around one and hence market risk factor is an important factor to explain returns over risk free rate but does not explain variation in excess stock return.

The explanatory power of three-factor model is further supported by the adjusted R-Square values (see Table 3) which are found high for all six portfolios. We find all three factors to be significant and hence we determine that all three factors are significant in explaining excess portfolio returns. 


\section{Summary and Conclusions}

The aim of our study is to check if Fama and French three-factor model holds true for Pakistani equity market. According to Fama and French $(1992,1993)$, the three-factor model does a better job than the CAPM at explaining cross-sectional variation in average stock returns. In CAPM only market risk factor is used to explain excess stock returns, however Fama and French three-factor model incorporates two other risk factors to the CAPM, which are risk related to firms' size and risk related to firms' book-to-market equity. In order to check if the model holds true for Pakistani equity market we use companies listed on KSE-100 index from July, 2004 to June, 2014. We form 6 portfolios by intersection of 2 size and 3 book-to-market equity portfolios. Monthly value weighted return of each portfolio is regressed against monthly market premium (Rm-Rf), Size premium (SMB) and Value premium (HML). Estimation results show that the model holds true for stocks listed on KSE-100 from July, 2004 to June, 2014. Our estimation results are also in line with Fama and French $(1992,1993)$ study results which show that higher return on small stocks is explained by difference in the slope of small and big stocks with positive average SMB return. Our estimation results show that the slope of small stocks is higher than the slope of big stocks and average return on $\mathrm{SMB}$ is also found to be positive. Moreover we also find that value stocks (High B/M stocks) have higher return than growth stocks (low $\mathrm{B} / \mathrm{M}$ stocks). Our estimation results show that all three-factors are significant in explaining cross-sectional variation in average stock returns and hence the three-factor does a good job at explaining cross-sectional average returns.

\section{References}

Adrain, \& Franzoni. (2002). Learning About Beta: An Explanation of the Value Premium. Journal of Financial Economics.

Aksu, \& Onder. (ca. 2003). The Size and Book-To-Market Effects and Their Role as Risk Proxies in the Istanbul Stock Exchange.

And, \& Chen. (2005). CAPM over a Long Run: 1926-2001. The National Bureau of Economic research, paper no. 11903

Anderson, \& Feijóo. (2006). Empirical Evidence on Capital Investment, Growth Options, and Security Returns. The Journal of Finance, 61(1), 171-194, Wiley.

Asness, et, al. (2013). Value and Momentum Everywhere. The Journal of Finance, 68(3), 929-985, American Finance Association.

Awwaliyah, \& Husodo. (2011). On the Robustness of the Extended Fama-French Three Factor Model.

Banz. (1981). The Relationship Between Return and Market Value of Common Stocks. Journal of Financial Economics, 3-18, North-Holland.

Berk. (1995). A critique of size related anomalies. Review of Financial Studies, 8, 275-286

Berk. (1997). Does Size Really Matter. Financial Analysts Journal, 53(5), 12-18, CFA Institute.

Bollerslev. (1988). A Capital Asset Pricing Model With Time-varying Covariances. Journal of Political Economy, 96(1), 116-131, The university of Chicago Press.

Borchert, et, al. (2003). Understanding Risk and Return, the CAPM, and the Fama-French Three-Factor Model. Tuck School of Business, No. 03-111.

Borys, \& zemcik. (2006). Size and Value Effects in the Visegrad Countries. Economics Institute of the Academy of Sciences of the Czech Republic.

Bryant, \& Elsewaparu. (1997). Cross-Sectional Determinants of New Zealand Share Market Returns. Journal of Accounting and Finance, 37(2), 181-205

Bundoo. (2005). An Augmented Fama and French Three-Factor Model: New Evidence From An Emerging Stock Market. Department of Economics \& Statistics, University of Mauritius.

Capaul, et, al. (1993). International Value and Growth Stock Returns. Financial Analysts Journal, 49(1), 27-36, CFA Institute.

Chan, \& Lakonishok. (2004). Value and Growth Investing: Review and Update. Financial Analysts Journal, 60(1), 71-86, CFA Institute

Chung, et, al. (2006). Asset Pricing When Returns Are Nonnormal: Fama - French Factors versus Higher - Order Systematic Comoments. The Journal of Business, 79(2), 923-940, The University of Chicago Press. 
Connor, \& Sehgal. (2001). Tests of the Fama and French Model in India.

Daniel, et, al. (2001). Explaining the Cross-Section of Stock Returns in Japan: Factors or Characteristics?. The Journal of Finance, 56(2), 743-766, Wiley.

Davis, et, al. (2000). Characteristics, Covariances, and Average Returns: 1929 to 1997. The Journal of Finance, 55(1), 389-406, Wiley.

De Bondt, \& Tharler. (1985). Does Stock Market Overreact?. The Journal of Finance, 40(3), 793-805. http://dx.doi.org/10.1111/j.1540-6261.1985.tb05004.x

De Bondt, \& Tharler. (1989). Anomalies: A Mean-Reverting Walk Down Wall Street. The Journal of Economkc Perspectives, 3(1), 189-202. http://dx.doi.org/10.1257/jep.3.1.189

De Bondt, \& Tharler. (1990). Do Security Analyst Overreact?. The American Economic Review, 80(2), 55-57, Amercan EconomicAssociation.

Djajadikerta, \& Nartea. (2005). The Size and Book-to-Market Effects and the Fama-French Three-Factor Model in Small Markets: Preliminary Findings from New Zealand. Accounting, Finance and Economics \& FIMARC.

Ebrahim, et, al. (2013). Rationalizing the Value Premium: Evidence from Malaysia. United Kingdom.

Elgers, \& Murray (1982). The Impact of the Choice of Market Index on the Empirical Evaluation of Accounting Risk Measures. The Accounting Review, 57(2), 358-375, American Accounting Association.

Eraslan. (2013). Fama and French Three-Factor Model: Evidence from Istanbul Stock Exchange. Business and Economics Research Journal, 4(2), 11-22.

Fama, \& Feench. (2007). Migration. Financial Analysts Journal, 63(3), 48-58, CFA Institute.

Fama, \& French. (1989). Business Conditions and Expected returns on Stocks and Bond. Journal of Financial Economics, 25, 23-49, North Holland.

Fama, \& French. (1992). The Cross-Section of Expected Stock Returns. The Journal of Finance, XLVII(2).

Fama, \& French. (1995). Size and Book-to-Market Factors in Earnings and Returns. The Journal of Finance, 50(1), 131-155, Wiley.

Fama, \& French. (1996). Multifactor Explanations of Asset Pricing Anomalies. The Journal of Finance, 51(1), 55-84, Wiley.

Fama, \& French. (2004). The Capital Asset Pricing Model Theory and Evidence. Journal of Economic Perspectives, 18(3), 25-46, American Economic Association.

Fama, \& French. (2006). The Value Premium and the CAPM. The Journal of Finance, 61(5), 2163-2185, Wiley.

Fama, \& French. (2012). Size, value, and momentum in international stock returns. Journal of Financial Economics, 105(3), 457-472.

Fama, et, al. (1993). InstituteDifferences in the Risks and Returns of NYSE and NASD Stocks. Financial Analysts Journal, 49(1), 37-41, CFA Institue.

Fama. (1998). Long Term Returns. Journal of Financial Economics, 49(3), 283-306.

Fehle, et, al. (2008). Quarterly Journal of Finance and Accounting, 47(1), 3-26, University of Nebraska-Lincoln College of Business Administration.

Ferguson, et, al. (1999). Equilibrium “Anomalies”. Journal of Finance, 58(6), 2549-2580.

Fernandize. (2002). The CAPM and Value at Risk at Different Time Scales. Chile, Center for Applied Economics.

Ferson, \& Seigel. (2006). Testing Portfolio Efficiency with Conditioning Information. The National Bureau of Economic research.

Garza-Gómez. (2001). The Information Content of the Book-to-Market Ratio. Financial Analysts Journal, 57(6), 78-95, CFA Institute.

Gibbons. (1982). Multivariate Tests of Financial Models: A New Approach. Journal of Financial Economics, 10(1), 3-27.

Griffin, \& Lemmon. (1995). Book-to-Market Equity, Distress Risk, and Stock Returns. The Journal of Finance, $57(5)$. 
Griffin, \& Lemmon. (2002). Book-to-Market Equity, Distress Risk, and Stock Returns. The Journal of Finance, 57(5), 2317-2336, Wiley.

Griffin. (2002). Are the Fama and French Factors Global or Country Specific?. The Review of Financial Studies, 15(3), 783-803, Oxford University Press.

Guan, et, al. (2007). Stable betas, size, earnings - to - price, book - to - market and the validity of the capital asset pricing model. Managerial Finance, 33(8), 595-614.

H. Bower, et, al. (1984). Arbitrage Pricing Theory and Utility Stock Returns. The Journal of Finance, 39(4), 1041-1054, Wiley. http://dx.doi.org/10.1111/j.1540-6261.1984.tb03891.x

Hahn, \& Lee. (2006). Yield Spreads as Alternative Risk Factors for Size and Book-to-Market. Journal of Financial and Quantitative Analysis, 41(2).

Hamid, et, al. (2012). Fama and French Three Factor Model: Empirical Evidence from Financial Market of Pakistan. African Journal of Business Management, 6(8), 2945-2950.

Hibbert, \& Lawrence. (2010). Testing the performance of asset pricing models in different economic and interest rate regimes using individual stock returns. International Journal of Banking and Finance, 7(1).

Hung, et, al. (2004). CAPM, Higher Co-moment and Factor Models of UK Stock Returns. Journal of Business Finance \& Accounting, 31, 87-112.

Jagadeesh, \& Titman. (1993). Returns to Buying Winners and Selling Losers: Implications for Stock Market Efficiency. The Journal of Finance, 48(1), 65-91.

Jain. (2013). Fama-French Three Factor Model in Indian Stock Market. The Current Global Trends, 2(1), Sci-edit Publications.

Jensen, et, al. (1997). New Evidence on Size and Price-to-Book Effects in Stock Returns. Financial Analysts Journal, 53(6), 34-42, CFA Institute.

Kim. (1997). A Reexamination of Firm Size, Book-To-Market, and Earnings Price in the Cross-Section of Expected Stock Returns. The Journal of Financial and Quantitative Analysis, 32(4), 463-489, Cambridge University Press.

Klein, \& Chow. (2002). Sentiment Effect and Market Portfolio Inefficiency. Journal of economics.

Kothari, et, al. (1995). Another Look at the Cross-Section of Expected Stock Returns. The Journal of Finance, 50(1), 185-224, Wiley.

Lakonishok, et, al. (1995). Contrarian Investment, Extrapolation, and Risk. Journal of Finance, 49(5), 1541-1578, Blackwell.

Lam. (2005). Is Fama-French Three Factor Model better than the CAPM?. W.A.C Bennett Library, Simon Fraser University.

Leleux, et, al. (1996). Pricing High Growth Firms: Arbitrage Opportunities in the Inc. 100. The Journal of Entrepreneurial Finance, 5(4).

Lettau, \& Ludvigson. (2001). Resurrecting the CAPM: A Cross-Sectional Test When Risk Premia Are Time-Varying. Journal of Political Economy, 109(5).

Loughran. (1997). Book-To-Market across Firm Size, Exchange, and Seasonality: Is There an Effect?. The Journal of Financial and Quantitative Analysis, 32(3), 249-268, Cambridge University Press.

MacKinley. (1994). Multi Factors do not explain deviations from the CAPM. Journal of Financial Economics, 35 , 3-28.

Mc Donald, et, al. (1990). Predicting Stock Returns in an efficient Market. Journal of finance, 45, $1109-1128$. http://dx.doi.org/10.1111/j.1540-6261.1990.tb02429.x

Merton. (1973). An Intertemporal Capital Asset Pricing Model. Econometrica, 41(5), 867-887, The Econometric Society.

Mirza, \& Shahid. (2008). Size and Value Premium in Karachi Stock Exchange. The Lahore Journal of Economics, $1-26$.

Moerman. (2005). How Domestic is the Fama and French Three-Factor Model? An Application to the Euro Area, Erasmus Research Institute of Management. 
Pastor, \& Stambaugh. (2003). Liquidity Risk and Expected Stock Returns. Journal of Political Economy, 111(3).

Perasan, \& Timmermann. (1995). Predictability of Stock Returns: Robustness and Economic Significance. Journal of finance, 50(4), 1201-1228, American Finance Association.

Phalippou. (2007). Can Risk-Based Theories Explain the Value Premium?. Review of Finance, 11(2), 143-166.

Rafi, et, al. (2014). Validity of Fama and French Model: Evidence from KSE-100 index. International Journal of Management Science, 55-57.

Rahim, \& Mohd. Nor. (2006). A Comparison Between Fama and French Model and Liquidity-Based Three-Factor Models in Predicting the Portfolio Returns. Asian Academy of Management Journal of Accounting and Finance, 2, 43-60.

Rasul. (2013). Explanation of Value Premium on the Dhaka Stock Exchange: Risk and Firm Size. International Journal of Economics, Finance and Management, 2(6).

Reinganum. (1981). Misspecification of Capital Asset Pricing: Empirical Anomalies based on earnings' yield and market values. Journal of Financial Economics, 9(1), 19-46.

Rogers, \& Securato. (2007). Comparative Study of CAPM, Fama and French Model and Reward Beta Approach in the Brazilian Market.

Ross. (1976). The Arbitrage Theory of Capital Asset Pricing. Journal of Economic Theory, 13(3), 341-360

Santhi, \& Gurunathan. (2014). Fama-French Three Factors Model in Indian Mutual Fund Market. Asian Journal of Economics and Empirical Research, 1, Asian online Journal Publishing Group.

Schwert. (2002). Anomalies and Market Efficiency. National Bureau of Economic Research.

Sehgal, \& Tripathi. (2004). Size Effect in Indian Stock Market: Some Empirical Evidence.

Sharpe. (1964). Capital Asset Prices: A theory of Market Equilibrium under Conditions of Risk. The Journal of Finance, 19(3), 425-442.

Vos, \& Pepper, (1997). The Size and Book-to-Market Effects in New Zealand. The New Zealand Investment Analyst, (18), 35-45.

Wu, \& Carr. (2008). Variance Risk Premiums. The Review of Financial Studies, 22.

Xu, \& Zhang. (2014). The Fama-French Three Factors in Chinese Stock Market. The Hong Kong Polytechnic University.

Zhang. (2005). The Value Premium. The Journal of Finance, 60(1), 67-103, Wiley.

\section{Notes}

Note 1. An Intertemporal Capital Asset Pricing Model (Merton, 1973)

Note 2. [Momentum Effect - Jegadeesh and Titman (1993), Cursatis, Miles and Woolridge (1993)]

Desai and Jain (1997) find long term positive abnormal returns both before and after split

Note 3. [Ball and Brown (1968), Bernard and Thomas (1990),

Note 4. Anderson et al. have stated in their paper that BE/ME and Size are correlated to firm-level investment activity ([Anderson and Feijóo (2006)]

Note 5. Indian Market - (Connor and Sehgal, 2001), (Sehgal and Tripathi, 2004), (Sahil Jain 2013), (Santhi et al. 2014)

Bangladesh - (Franzoni, 2002)

Africa - (Bundoo, 2005)

Pakistan - (Mirza and Shahid, 2008), (Rafi, et, al, 2014), (Rahim and Nor, 2006)

New Zealand - (Djajadikerta and Nartea, 2005), (Bryant and Elsewaparu, 1997), (Vos and Pepper, 1997)

Turkey - (Aksu and Onder, ca. 2003), (Ann Marie Hibbert and Edward R. Lawrence, 2010)

\section{Appendix}

The KSE-100 listed companies were selected as index re-composition on $19^{\text {th }}$, September, 2014. 